\title{
MACROECONOMIC EFFECTS OF INTRODUCING A CAPITAL CONSERVATION BUFFER IN THE UKRAINIAN BANKING SECTOR
}

\section{PERVIN DADASHOVAa , MAGNUS JONSSON ${ }^{\mathrm{b}}$, HANNA ONYSHCHENKO ${ }^{\text {* }^{*}}$}

aNational Bank of Ukraine; National University of "Kyiv-Mohyla Academy"

Email: pervin.dadashova@bank.gov.ua

bSveriges Riksbank

Email: magnus.jonsson@riksbank.se

National Bank of Ukraine

Email: hanna.onyschenko@bank.gov.ua

Abstract

The National Bank of Ukraine (NBU) is planning to introduce a capital conservation buffer in the Ukrainian banking sector over a four-year period starting in 2020. This new regulation will yield long-term benefits by strengthening the resilience of the banks, which will reduce the likelihood and costs of financial crises. However, higher capital requirements in the form of a capital conservation buffer can also result in shortterm costs by temporarily lowering output. In this study, we use a dynamic general equilibrium model calibrated to fit some long-term features of the Ukrainian economy to evaluate how different implementation strategies affect the short-term output loss. We show that the output loss can be reduced by preannouncing and gradually implementing the buffer, along the lines that have already been advanced by the NBU.

JEL Codes E17, E58, G21

Keywords capital buffers, DSGE models, banks, macroeconomic costs, macroprudential policy, Ukraine

\section{INTRODUCTION}

The financial crisis that hit Ukraine in 2014-2015 had destructive effects on the economy and the Ukrainian banking sector. This crisis - which was only the latest in a series of crises that have hit Ukraine since independence - made it clear that a large-scale transformation of the financial sector was necessary. Hence, in 2015 the National Bank of Ukraine (NBU) announced its intention to gradually introduce new capital requirements for banks, following Basel III standards. In addition to new capital adequacy ratios, the new requirements include a capital conservation buffer, a countercyclical capital buffer, and a systemic capital buffer for systemically important banks.

Bank capital is key in promoting financial stability and resilience of the financial system. The greater the banks' capital, the less likely are financial crises, and the less damaging are those that do occur. However, higher capital requirements can also be associated with short-term costs. A rapid increase in capital requirements can lead to a reduction in lending, which in turn can have negative short-term effects on output and economic performance. In principle, these short-term costs can be reduced by giving banks time to adjust to the new requirements. Stricter requirements can, for example, be announced some time in advance and/or they can be introduced gradually. This gives banks time to adjust, using either retained earnings or external capital issuance.

In this study, we evaluate how different implementation strategies for introducing stricter capital requirements affect economic performance. As a case in point, we consider the introduction of the conservation buffer in the Ukrainian banking sector. The buffer is accumulated in periods of economic growth, and is used to offset potential losses incurred during economic recessions. The NBU plans to increase the buffer's size over a four-year period starting in 2020 , by 0.625 percentage points each year. In 2023 , when the buffer is fully implemented, it will reach 2.5 percent.

The analysis uses a dynamic general equilibrium model calibrated to fit the main features of the Ukrainian economy. We evaluate four different implementation strategies in terms of how well they minimize the fall in short-term output. 
The first strategy introduces the buffer immediately, without prior announcement. The second strategy sees the buffer being announced some time in advance, i.e., the implementation is "preannounced". The third strategy considers a gradual implementation of the buffer that is immediately implemented. The fourth and final strategy approximates the actual strategy advanced by the NBU, of first preannouncing the buffer's introduction and then gradually implementing it. We find that the short-term output loss is minimized by preannouncing and gradually implementing the buffer along the lines that have been advanced by the NBU.

The rest of the paper is organized as follows: the next section discusses the regulators' response to the global financial crisis in 2008, and the benefits and costs of higher capital requirements. In the following section we give a brief review of the Ukrainian banking sector since independence, leading up to the current situation. Then we describe the modelling framework, how the model is calibrated to some long-term features of the Ukrainian economy, and give the results of the simulations. Finally, we provide some concluding comments.

\subsection{The 2008 global financial crisis, and the responses by regulators}

Financial crises are often associated with high economic costs, as the recent global financial crisis in 2008 demonstrated. One major lesson from this crisis was that more has to be done than simply supervising individual financial institutions; instruments are also required to prevent certain risks that threaten the financial system as a whole, so-called macroprudential policies. Furthermore, the capital requirements in place in 2008 proved insufficient to cover bank losses, and in several countries taxpayers had to supply new funds to fill the gap.

In the wake of the crisis, the Basel Committee on Banking Supervision drew up a new framework for banking regulations, the so-called Basel III (or the Third Basel Accord). One of the objectives of this new framework is to strengthen capital requirements compared to the earlier Basel II standard. In addition, Basel III introduces new liquidity requirements, i.e., a liquidity coverage ratio, and a net stable funding ratio.

The minimum bank capital requirements in Basel III are raised from 8 percent, up to 15.5 percent of risk-weighted assets (RWA) compared to Basel II. ${ }^{1}$ Moreover, Basel III introduces a leverage ratio requirement of 3 percent. The difference between capital requirements in terms of a risk-weighted capitalto-asset ratio and a leverage ratio can be understood by considering a simplified balance sheet of a bank.

\subsection{Defining Capital and Leverage Ratios}

Assume a bank with two types of assets - loans to households $L^{H}$ and loans to entrepreneurs (or firms) $L^{E}$. The liabilities consist of deposits from the public $D$ and capital (or equity) $K$. In this case, the balance sheet of the bank will be as follows,

$$
L^{H}+L^{E}=D+K
$$

The risk-weighted capital-to-asset ratio $\kappa^{R W A}$ is then defined as follows,

$$
\kappa^{R W A}=\frac{K}{\omega_{H} L^{H}+\omega_{E} L^{E}}
$$

where $\omega_{H} L^{H}+\omega_{E} L^{E}$ is the bank's risk-weighted loans and the parameters $\omega_{H}$ and $\omega_{E}$ denote the risk weights on household loans and firm loans, respectively. The risk weights are supposed to reflect the riskiness of the loans. If a specific category of loans are associated with higher risk, this category will have a higher risk weight. For example, firm loans are often considered more risky than household loans, which implies that in our example $\omega_{E}$ is higher than $\omega_{H}$.

As long as the risk weight reflects the actual riskiness of the loans, regulations based on risk-weighted requirements can make capital allocation in the economy more efficient. However, risk weights are calculated by the banks' own internal methods; or as is the case in Ukraine by the NBU. If for some reason the riskiness of the loans is underestimated, then the risk weights will be too low and, as a consequence, the capital requirements will be too low. This is one reason why the capital requirements in Basel III are complemented with a leverage ratio $\kappa^{\text {Leverage }}$, which is a requirement on capital in relation to total lending, i.e.,

$$
\kappa^{\text {Leverage }}=\frac{K}{L^{H}+L^{E}} .
$$

The leverage ratio may thus complement the risk-weighted capital-to-asset ratio in order to ensure the resilience of the banking sector.

\subsection{The benefits and costs of capital re- quirements}

The starting point when discussing the benefits and costs of capital regulations is often the so-called ModiglianiMiller theorem, according to which capital requirements are both costless and redundant. ${ }^{2}$ However, a number of conditions must be true for this to be the case. There should, for example, be no tax deductibility of interest rate costs, no bankruptcy costs, and no asymmetric information between borrowers and lenders. One can argue about the relative importance of each of these frictions, but it is unlikely that the Modigliani-Miller theorem would hold exactly. Requiring a certain capital-to-asset ratio can therefore play an important role in giving banks incentives to behave in a socially optimal fashion.

Bank capital requirements promote financial stability by reducing the probability of banking crises, and the costs of financial crises. If banks are well-capitalized, ex ante incentives to take on excessive risk are reduced. Bank capital requirements also act as an ex post buffer against bank losses. In other words, higher capital requirements reduce both the likelihood and the costs of financial crises by strengthening the resilience of the banking sector. However, capital requirements can also be associated with costs - both short-

\footnotetext{
${ }^{1}$ This is the case when all different requirements in Basel III are activated, i.e., minimum total capital, the conservation buffer, the countercyclical buffer, and the global systemically important banks charge.

${ }^{2}$ See Modigliani and Miller (1958) and Dagher et al. (2016) for a detailed discussion of the costs and benefits of capital requirements.
} 
term and long-term. ${ }^{3}$ Raising new capital can, for example, be subject to non-negligible underwriting fees and signaling costs. ${ }^{4} \mathrm{~A}$ rapid increase in capital requirements can, as a consequence, lead to reductions in lending, which in turn may have negative effects on output and economic performance.

The short-term output loss of higher capital requirements can in principle be mitigated by giving banks time to adjust. For example, stricter requirements can be announced some time in advance, or they can be introduced gradually, or these two strategies can be combined. This gives banks time to adjust their capital buffers, using either retained earnings or external capital issuance. This may not always be possible, however. There can be circumstances in which, for example, market pressure force banks to adjust rapidly.

\subsection{Capital requirements in Ukraine}

In light of two severe financial crises, in 2008 and 2014 , the NBU took an important step towards strengthening the banking sector by introducing amendments to the law On the National Bank of Ukraine. These amendments gave the $\mathrm{NBU}$, among other things, the responsibility to develop and implement macroprudential policies. One of the key instruments in the NBU's macroprudential toolkit is capital requirements.

The current capital requirement of 10 percent in Ukraine will be supplemented with different capital buffer requirements, i.e., a capital conservation buffer, a systemic capital buffer, and a countercyclical capital buffer. The main purpose of the capital conservation buffer is to ensure that the banks can maintain the desired level of capital when times are bad. The conservation buffer is composed of high quality capital items (common equity tier 1 capital) to absorb potential losses during recessions. The buffer will be set at 0.625 percent in 2020 , and over the next three years it will be increased by a further 0.625 percentage points each year, until it reaches 2.5 percent in 2023 .

The systemic capital buffer requirement is similar to the conservation buffer, but it is applied to systemically important banks. This requirement can vary between 1 and 2 percent, depending on the importance of the bank. The NBU will decide, sometime after 2020, when this buffer will be activated, based on the economic and financial conditions in Ukraine.

Finally, risks in the financial system can be divided into cyclical and structural risks. Macroprudential instruments can also be divided along these lines, i.e., cyclical and structural instruments. Cyclical instruments are intended to change over time in response to changes in, for example, financial imbalances. Structural instruments, on the other hand, are intended to be implemented "once and for all" to create a safe and stable long-term financial environment. The countercyclical capital buffer is an example of a cyclical instrument. In times when borrowing by households and firms is rising rapidly, the buffer requirement is increased. Conversely, when banks exercise more restraint in their lending, the buffer can be reduced. Like the conservation and systematic buffers, the countercyclical buffer consists of common equity tier 1 capital. The introduction of this buffer will - just as for the systematic buffer - depend on the economic and financial conditions after 2020

\section{A DYNAMIC GENERAL EQUILIBRIUM MODEL FOR STUDYING CAPITAL REQUIREMENTS}

To study the effects of higher capital requirements in the form of a conservation buffer, we use a dynamic general equilibrium model. In contrast to so-called partial equilibrium models - which restrict their attention to a particular market, taking the price of other goods as given - general equilibrium models are characterized by the interaction between different markets, which among other things recognizes that prices in different markets can be determined jointly. That the model is dynamic means that the time dimension of economic decisions is accounted for. Typically, economic decisions involve a time or "intertemporal" dimension - examples include consumption and saving decisions, investment decisions, deficit-finance decisions, etc.

The model economy is formally described and explained in lacoviello (2015). In this section, we only provide a brief description of the maximization problems of the economic agents, i.e., households, entrepreneurs, and banks.

\subsection{Households}

Households, denoted by subscript $H$, choose consumption, housing services, one-period deposits, and leisure subject to a budget constraint in order to maximize expected utility. Formally, they are maximizing the following utility function:

$$
\max E_{0} \sum_{t=0}^{\infty} \beta_{H}^{t}\left(\ln C_{H, t}+\omega \ln H_{H, t}+\tau \ln \left(1-N_{H, t}\right)\right),
$$

where $\beta$ denotes the subjective discount factor, $C_{H}$ consumption, $H_{H}$ housing services, and $N_{H}$ time spent working (note that time is normalized to one, which means that leisure equals one minus time spent working). The parameters $\omega$ and $\tau$ determine the weight households put on housing services and leisure, respectively, in the utility function. The maximization is subject to the following budget constraint:

$$
C_{H, t}+D_{H, t}+q_{t}\left(H_{H, t}-H_{H, t-1}\right)=R_{D, t-1} D_{H, t-1}+W_{t} N_{H, t},
$$

where $D_{H}$ denotes one-period deposits, $R_{D}$ gross return on deposits, $q$ the price of real estate, and $W$ the real wage rate. Households save part of their income by providing loans - intermediated by the banks - to the entrepreneurs. Households are thus financing part of the production in the economy. Income consists of wages and interest on savings. The income is spent on consumption, housing services and savings in bank deposits.

\footnotetext{
${ }^{3}$ In this study, we focus on the short-term costs. In the model, there is no long-term effect on GDP growth of permanent higher capital requirements, although there is a negative level effect.
}

${ }^{4}$ See Myers and Majluf (1984). 


\subsection{Entrepreneurs}

Entrepreneurs (can be interpreted as small self-employed firms) produce the economy's output. They are denoted by subscript $E$ and they choose consumption, commercial real estate, loans from the banks, and labor input, to maximize expected utility:

$$
\max E_{0} \sum_{t=0}^{\infty} \beta_{E}^{t} \ln C_{E, t}
$$

subject to a budget constraint:

$$
\begin{aligned}
& C_{E, t}+q_{t}\left(H_{E, t}-H_{E, t-1}\right)+R_{L, t} L_{E, t-1}+ \\
& +W_{t} N_{E, t}+\gamma \frac{\left(L_{E, t}-L_{E, t-1}\right)^{2}}{\overline{L_{E}}}=Y_{t}+L_{E, t}
\end{aligned}
$$

where $R_{L}$ denotes the one-period (gross) loan rate, $Y$ output, $H_{E}$ commercial real estate, $L_{E}$ loans and $\left(L_{E, t}-L_{E, t-1}\right)^{2} / \overline{L_{E}}$ the loan portfolio adjustment cost function, where $\overline{L_{E}}$ is the steady state level of loans extended to the entrepreneurs. The parameter $\gamma$ determines how costly it is to change the loan portfolio. The budget constraint says that the entrepreneurs' resources, i.e., income from production and loans from banks, are spent on consumption, real estate, interest rates on loans, wages, and the adjustment costs of changing the loan portfolio.

Input in production is mainly labor from households, but a relatively small share (about 5 percent) consists of commercial real estate. We assume a standard Cobb-Douglas production function:

$$
Y_{t}=H_{E, t-1}^{\alpha} N_{E, t}^{1-\alpha}
$$

where the parameter $\mathrm{a}$ is the share of real estate in production. Entrepreneurs cannot borrow more than a fraction $\theta$ of the expected value of the real estate stock, and, following lacoviello (2015), we also assume that the wage bill must be paid in advance:

$$
L_{E, t} \leq \theta E_{t} \frac{q_{t+1}}{R_{L, t+1}} H_{E, t}-W_{t} N_{E, t}
$$

\subsection{Banks}

Banks, denoted by subscript $B$, intermediate loans between households and entrepreneurs. They maximize expected utility, which can be interpreted as if they are maximizing a convex function of dividends. Formally, they choose consumption, deposits, and loans to entrepreneurs, to solve the following maximization problem:

$$
\max E_{0} \sum_{t=0}^{\infty} \beta_{B}^{t} \ln C_{B, t}
$$

subject to a budget constraint:

$C_{B, t}+R_{D, t-1} D_{B, t-1}+L_{B, t}+\gamma \frac{\left(L_{B, t}-L_{B, t-1}\right)^{2}}{\overline{L_{B}}}=D_{B, t}+R_{L, t} L_{B, t-1}$.
Banks use deposits and interest rates on loans to pay for consumption (which as noted can be interpreted as dividends), interest rates on deposits, and new loans to entrepreneurs. The conversion of deposits into loans is also subject to a portfolio adjustment cost, $\left(L_{B, t}-L_{B, t-1}\right)^{2} / \overline{L_{B}}$, where $\overline{L_{B}}$ is the steady state level of loans extended by the bank.

In addition, banks are limited in extending loans by a capital requirement $\kappa$ :

$$
\kappa \leq \frac{K_{B, t}}{L_{B, t}}
$$

where $K_{B}$ denotes bank capital. Note that $K_{B, t}=L_{B, t}-D_{B, t}$. Bank capital is therefore determined residually.

Finally, the following market clearing conditions must hold in equilibrium,

$$
\begin{gathered}
H_{H, t}+H_{E, t}=1, \\
N_{H, t}=N_{E, t}, \\
D_{H, t}=D_{B, t}, \\
L_{E, t}=L_{B, t}, \\
C_{H, t}+C_{E, t}+C_{B, t}+\gamma \frac{\left(L_{B, t}-L_{B, t-1}\right)^{2}}{\overline{L_{B}}}+\gamma \frac{\left(L_{E, t}-L_{E, t-1}\right)^{2}}{\overline{L_{E}}}=Y_{t} .
\end{gathered}
$$

\subsection{Calibration to Ukrainian data}

In order to run a simulation with the model, its the parameters must be assigned values. We calibrate the parameter values to ensure that some long-term features of the model are in line with Ukrainian data. In practice there are two types of parameters. The first type affects mainly the long-term characteristics of the model, i.e., the steady state values. These are the parameter values that we calibrate. The second type of parameters mainly reflects short-term dynamics. For these parameters it is typically not possible to find an observable equivalent in the data. In the model there are two parameters of this type - the parameter that determines the cost for banks of adjusting lending, and the parameter that determines the cost for entrepreneurs of adjusting their borrowing. For these two parameters, we use the estimated values in lacoviello (2015).

We calibrate the discount factors (for households, banks, and entrepreneurs) and the loan-to-value ratio of the entrepreneurs to match real deposit and lending rates in the Ukrainian banking sector, and the debt-to-GDP ratio in the corporate sector. We only consider data collected after the introduction of the inflation target in 2016, since this structural change is likely to make earlier data inaccurate in describing the Ukrainian economy going forward. The real household deposit rate is 5.3 percent in the data, while the corporate real lending rate is 7.3 percent. ${ }^{5}$ To calculate these real rates, we used inflation expectations from the NBU survey. We set the debt-to-GDP ratio at 29 percent, which is in line with the debt-to-GDP ratio observed in the Ukrainian corporate sector in 2017.

\footnotetext{
5 The deposit rate is determined by households' discount factor, $\left.5.3=100^{*}\left(\left(1 / \beta_{H}\right)^{4}\right)-1\right)$, while the expression for the lending rate is more complicated and involves endogenous variables.
} 
The weight on leisure in the utility function determines labor supply and hours worked. We set this parameter to ensure that households work on average about eight hours a day. We lack data on the housing value to GDP and the income share of real estate in production. Hence, we use the estimates from lacoviello (2015) for the weight on housing in the utility function and the income share of real estate. We set the capital-to-asset ratio equal to the current requirement of 10 percent. The calibrated parameter values are summarized in Table 1. advance, which is enough to illustrate the principal effects of preannouncing. The third strategy considers a gradual implementation that is immediately introduced. We allow the buffer to be gradually implemented over a four-year period. This approximately replicates the gradual part of the strategy advanced by the NBU. The final and fourth strategy approximately replicates the strategy advanced by the NBU. The buffer is preannounced, two years in advance, and is then gradually implemented over a four-year period.

Table 1. Parameter values

\begin{tabular}{lcl}
\hline & $\begin{array}{c}\text { Parameter } \\
\text { in model }\end{array}$ & Value \\
\hline Discount factor - households & $\beta_{H}$ & 0.9872 \\
Discount factor - banks & $\beta_{B}$ & 0.942 \\
Discount factor - entrepreneurs & $\beta_{E}$ & 0.94 \\
Weight on leisure in utility function & $\tau$ & 2.00 \\
Weight on housing services in utility function & $\omega$ & 0.075 \\
Share of real estate in production & $\alpha$ & 0.05 \\
Portfolio adjustment cost parameter & $\gamma$ & 0.125 \\
Loan-to-value ratio & $\theta$ & 0.925 \\
Capital-to-asset ratio & $\kappa$ & 0.10 \\
\hline
\end{tabular}

\section{MACROECONOMIC EFFECTS OF INTRODUCING A CAPITAL CONSERVATION BUFFER}

The NBU plans to introduce a capital conservation buffer starting in 2020. The buffer will be implemented over a period of four years, increasing by 0.625 percentage points each year. In 2023, when the buffer requirement is fully implemented, the buffer will be 2.5 percent. The NBU is thus following a strategy of preannouncing and then gradually implementing the buffer.

The short-term costs in terms of lower output associated with higher capital requirements depend, among other things, on how the requirements are implemented. ${ }^{6}$ We therefore evaluate the implementation strategy of the NBU against three other strategies. In the first, the buffer is immediately implemented, i.e., the implementation is not announced in advance to the public. The financial markets are taken by surprise, and the banks cannot gradually adjust their capital holdings. This is the benchmark case; not because it is a realistic strategy in practice, but because it gives an upper bound of the short-term costs.

In the second strategy, the NBU announces the introduction in advance. The NBU first announced the introduction of the capital conservation buffer in 2015. However, in our simulation we consider an announcement of two years in
The different strategies are evaluated in terms of how well they minimize the short-term output loss. Hence, the evaluation does not account for the longer-term benefits that stricter requirements also imply - reductions in the likelihood of financial crises, and a lessening of their costs.

\subsection{Short-term output loss with immedi- ate implementation}

Consider first the benchmark case of immediate implementation. The NBU introduces a new buffer of 2.5 percent at the end of the first period, without informing the banks in advance, see Figure 1 in Appendix. ${ }^{7}$ In the next period, the banks therefore increase the capital-to-asset ratio from 10 to 12.5 percent. To fulfil the new buffer requirement, the banks can adjust capital or lending, or both. As we can see from the figure, the banks choose to adjust both capital and lending.

In the long-term the increase in capital is almost 14 percent, and lending is decreased by about 9 percent. Changes in lending are associated with adjustment costs, which means that lending is only gradually adjusted towards the new long-term value. This means that banks must immediately raise new capital above the long-term level in order to fulfil the buffer requirement. Capital increases by about 24 percent initially. After this initial increase, capital slowly decreases towards the long-run level.

\footnotetext{
${ }^{6}$ This study focuses on short-term effects, but also long-term effects can be of interest, see for example the study by Finocchiaro et al. (2016) who evaluates the long-term effects of different macroprudential policies.

${ }^{7}$ Each period is a quarter.
} 
Entrepreneurs' production costs are partially financed by bank loans. The fall in lending reduces the entrepreneurs' options for financing production. Hence, they hire less labor and hours worked fall, which inhibits production and, as a consequence, output falls. The fall in output implies that the debt-to-GDP ratio initially increases, even though lending is falling. This is, however, only an initial increase, and the debtto-GDP ratio subsequently falls. In the long-term, the debtto-GDP ratio falls from 29 to 26 percent.

The initial fall in output also implies that fewer resources can be used for consumption. After an initial fall in consumption (not shown in the figures), consumption increases towards the long-term level. Marginal utility is thus decreasing - and consequently the "intertemporal marginal rate of substitution", i.e., the willingness to substitute (give up) consumption today for consumption tomorrow, also increases throughout the transition. Since the marginal rate of substitution is positively associated with interest rates, there is upward pressure on deposit and lending rates. Moreover, upward pressure on the lending rate also comes from the entrepreneurs' borrowing constraint, which becomes more binding.

\subsection{Preannouncement can reduce the output loss}

One way to reduce the initial output loss is to announce the new buffer requirement in advance. The red line in Figure 2 shows the effects of preannouncing the buffer two years (eight periods in the figure) in advance. At the end of the first period, the NBU announces that the capital buffer will be raised by 2.5 percentage points in two years' time. This strategy is compared to the benchmark strategy of immediate implementation, i.e., the blue line.

By announcing the buffer in advance, the initial output loss is reduced. There is an initial fall in output when the announcement becomes public, by about 1 percent, and a slightly larger fall when the regulation is de facto implement- strategy is also compared to immediate implementation, i.e., the blue line. There is an initial decrease of output of about 1.5 percent. Output then gradually returns to its long-term value. The figure suggests that the cumulative output loss with gradual introduction is somewhat lower compared to immediate introduction.

\subsection{Gradual implementation and prean- nouncement minimize the output loss}

We have seen that both preannouncing and gradually implementing the buffer reduce the initial output loss. This suggests that a combination of preannouncing and gradual implementation is the most effective strategy in terms of minimizing the output loss. Figure 4 illustrates that this is indeed the case. In accordance with this strategy, the NBU announces at the end of period 1 that the buffer will be gradually implemented over a four-year period, starting two years from now. The red line shows this strategy, while the blue line shows immediate implementation.

The output loss is reduced compared to the benchmark strategy. Moreover, the effects on deposit and lending rates are also reduced (not shown in the figure). It is notable that the banks do not, to any great extent, adjust capital and lending until the buffer is formally introduced (not shown in the figure).

In Table 2 we show the cumulative output loss after four years, in terms of the percentage deviation of output from the long-term value, under the four different implementation strategies. If the buffer is immediately implemented, the cumulative output loss is about 3.4 percent. With preannouncing, the loss falls to about 2.3 percent, while by gradually implementing the buffer, the loss falls to about 3.2 percent. By both preannouncing and gradually implementing the buffer, the output loss is about 2.1 percent. This suggests that the NBU's strategy of both preannouncing and gradually implementing the capital buffer is the most effective strategy of the ones we have considered.

\section{Table 2. Cumulative output loss of different implementation strategies, in percent}

\begin{tabular}{lc}
\hline Implementation strategy & $\begin{array}{c}\text { Four years' cumulative } \\
\text { output loss }\end{array}$ \\
\hline Immediate & 3.4 \\
Preannounced & 2.3 \\
Gradual & 3.2 \\
Preannounced and gradual & 2.1 \\
\hline
\end{tabular}

ed. However, the cumulative output loss is lower compared to immediate implementation.

\subsection{Gradual implementation can also re- duce the output loss}

Another way to reduce the output loss is to implement the buffer gradually. The red line in Figure 3 shows the effect of implementing the buffer over a four-year period. This

\section{DISCUSSION}

The NBU has a dual mandate of promoting stable prices and financial stability. To promote financial stability the NBU supervises and regulates the banking sector. The NBU's aim is to follow the recommendations of the Basel Committee on Banking Supervision, the European Systemic Risk Board, EU Capital requirements regulations, and the corresponding EU directive (CRR/CRD IV). After the financial crisis in 2014 
and 2015, the NBU decided to introduce a capital conservation buffer (as well as systemic and countercyclical capital buffers) in order to increase the resilience of the Ukrainian banking sector. The introduction of the conservation buffer will start in January 2020.

In this article we studied how the introduction of a capital conservation buffer might affect the Ukrainian economy. In particular, we studied how different implementation strategies affect short-term costs in terms of lower output. The analysis was carried out through the lens of a dynamic general equilibrium model calibrated to fit some long-run features of the Ukrainian economy. We have shown that the output loss associated with the introduction of a capital conservation buffer can be reduced by preannouncing and gradually implementing the buffer, along the lines that have already been advanced by the NBU.

There are a few caveats, however: economic models are based on a number of simplifying assumptions regarding the decision-making of the economic agents and the features of the economic environment. Even though the mode is calibrated to fit some specific features of the Ukrainian economy, the results should be considered as calculated examples that illustrate and quantify some of the mechanisms at work, on the assumption that nothing else changes in the economy. In other words, the results should not be viewed as a conventional forecast of what will happen when the buffer is introduced.
Moreover, we have not carried out a formal analysis of which implementation strategy is optimal from a social welfare perspective. Output can, and often is, used as an approximation for social welfare. However, in our model, the utility function provides the formal measure of welfare, i.e., the sum of consumption, housing services and leisure (with various weights). The conclusions could thus potentially be different if we instead evaluated the different implementation strategies in terms of the utility functions of the agents. At the same time, there are arguments against this approach as well. For example, in actual economies, fluctuations in labor are primarily due to changes in the extensive margin (the number of individuals in employment) and to a lesser extent to changes in the intensive margin (the average number of working hours). In the model, all changes in labor are in the intensive margin, and we thus ignore the extensive margin. It could be argued that a formal welfare analysis that ignores the extensive margin (and the negative welfare effects of unemployment) may not give a more appropriate evaluation of welfare than a simple analysis that looks at output.

Finally, financial stability issues have not been accounted for in the analysis. To carry out an appropriate welfare analysis, the long-term benefits of higher capital requirements - in terms of a more resilient financial system - should ideally be evaluated against the short-term costs of lower output.

\section{REFERENCES}

- Bulletin of the National Bank of Ukraine (2001). February 2001, p. 143.

- Dagher J., Dell'Ariccia G., Laeven L., Ratnovski L., Tong H. (2016). Benefits and Costs of Bank Capital. IMF Staff Discussion Note, No. 16/04.

- Finocchiaro D., Jonsson M., Nilsson C., Strid I. (2016). Macroeconomic Effects of Reducing Household Debt. Sveriges Riksbank Economic Review, No. 2, pp. 57-88.
- lacoviello M. (2015). Financial Business Cycles. Review of Economic Dynamics, Vol. 18, No. 1, pp. 140-163.

- Modigliani F., Merton M. (1958). The Cost of Capital, Corporation Finance and the Theory of Investment. American Economic Review, Vol. 48, No. 3, pp. 261-297.

- Myers S., Majluf N. (1984). Corporate financing and investment decisions when firms have information that investors do not have. Journal of Financial Economics, Vol. 13, No. 2, pp. 187-221. 


\section{APPENDIX. FIGURES}

Figure 1. Macroeconomic effects of an immediate implementation of a conservation buffer of $\mathbf{2} .5$ percentage points

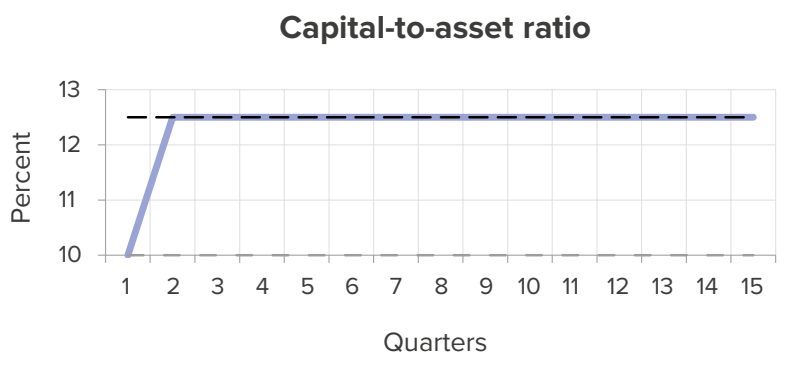

Bank capital gap

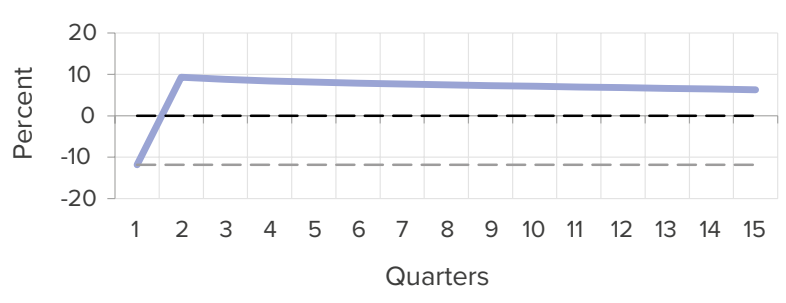

Debt-to-GDP ratio

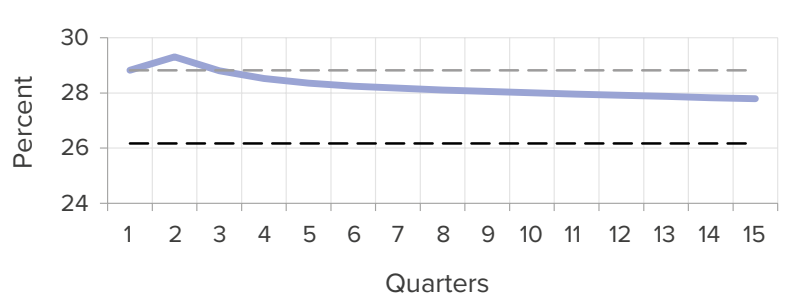

Lending rate

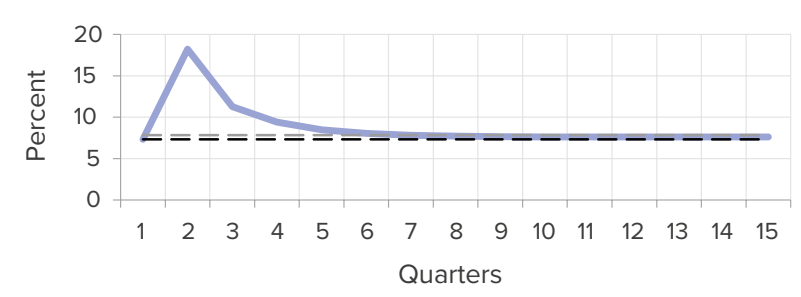

Output gap

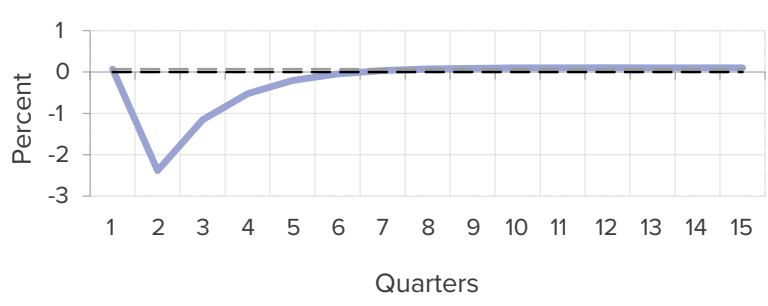

Lending gap

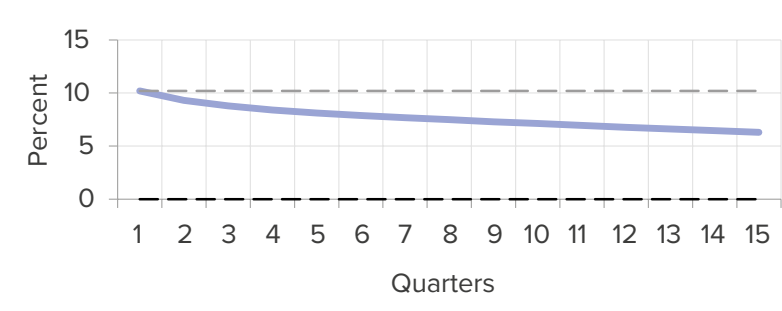

Labor gap

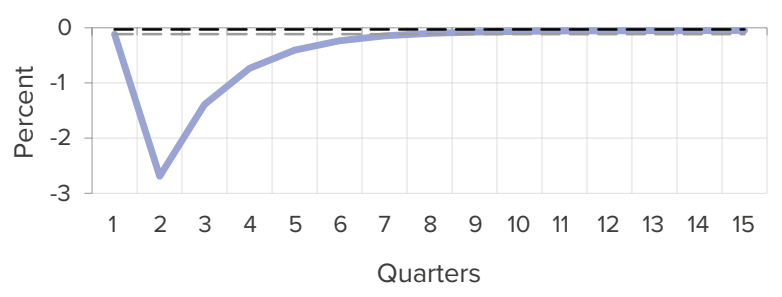

Deposit rate

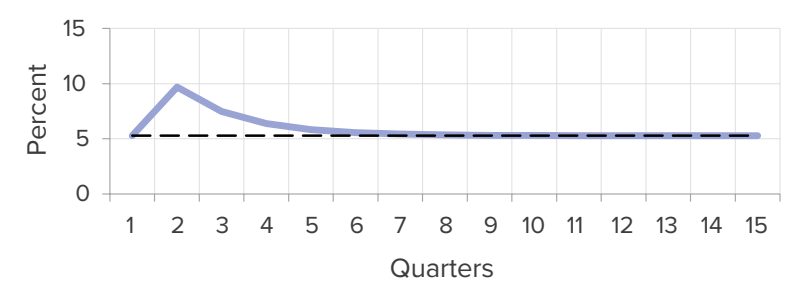


Figure 2. Macroeconomic effects of a preannounced implementation, two years in advance, of a conservation buffer of $\mathbf{2 . 5}$ percentage points compared to immediate implementation
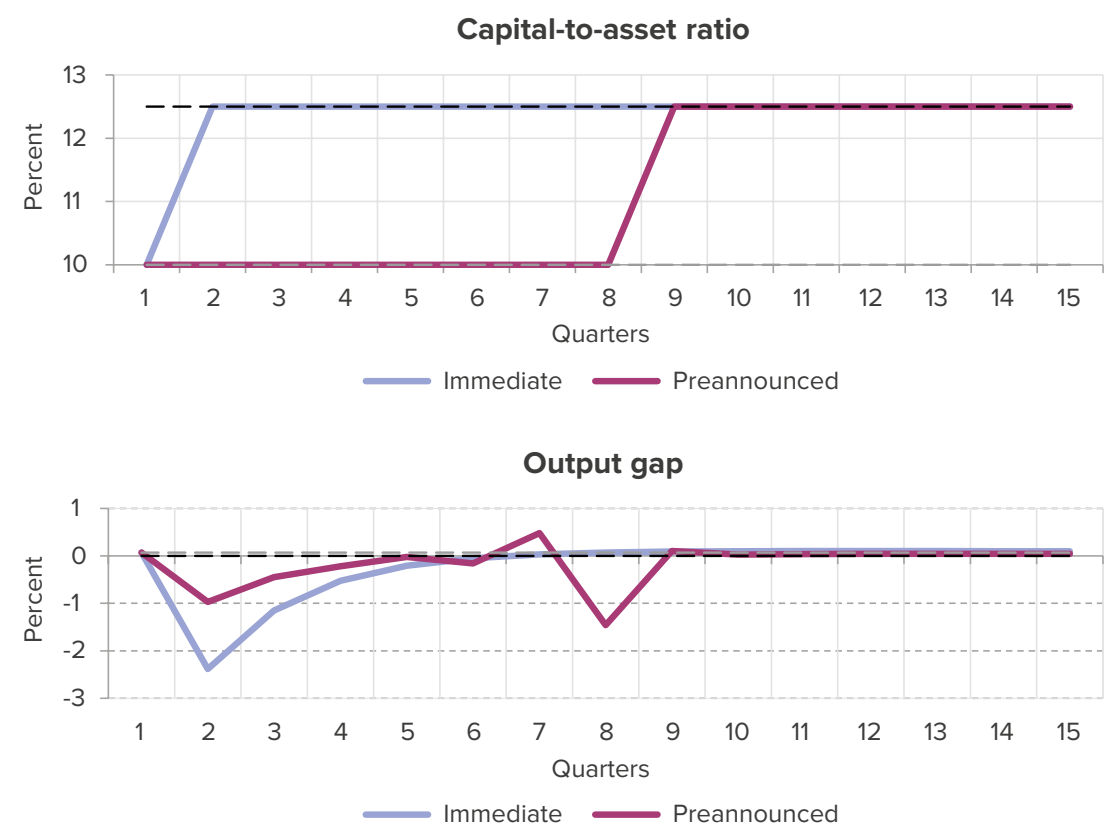

Figure 3. Macroeconomic effects of a gradual implementation of a conservation buffer of $\mathbf{2 . 5}$ percentage points over a four-year period, compared to immediate implementation
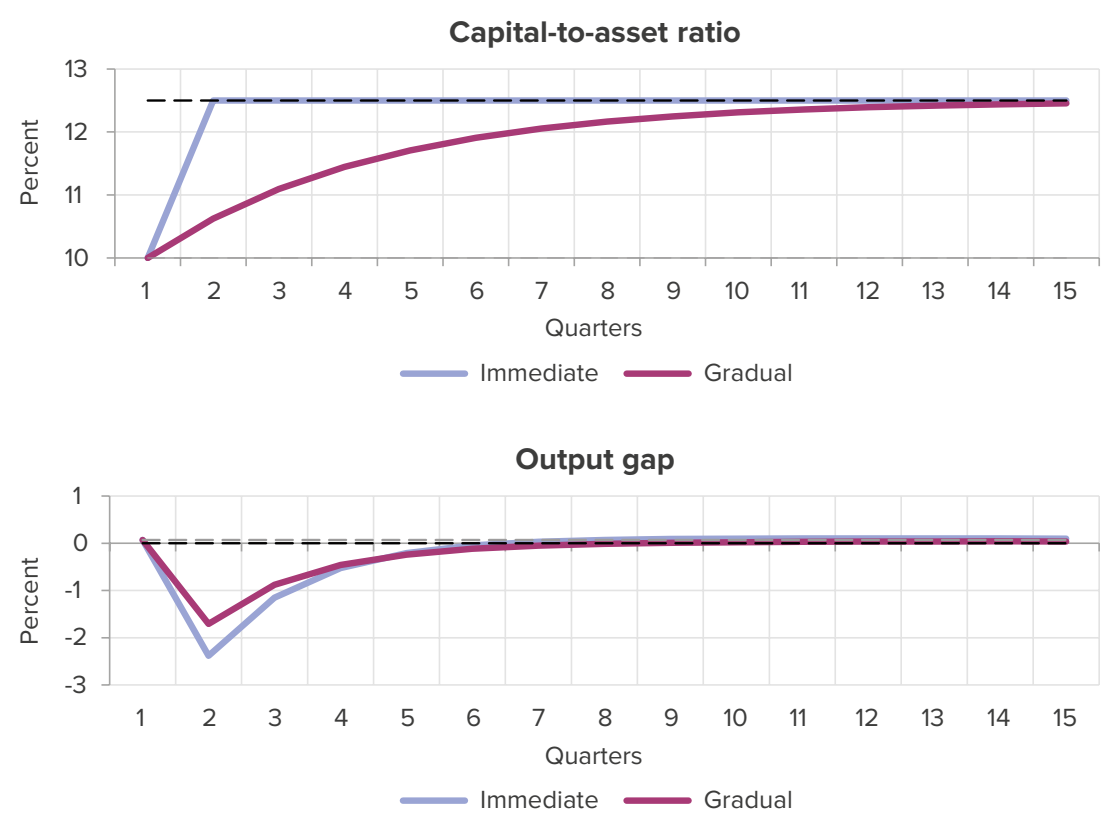
Figure 4. Macroeconomic effects of a combined preannounced, two years in advance, and a gradual, over a four-year period, implementation of a conservation buffer of $\mathbf{2 . 5}$ percentage points compared to immediate implementation
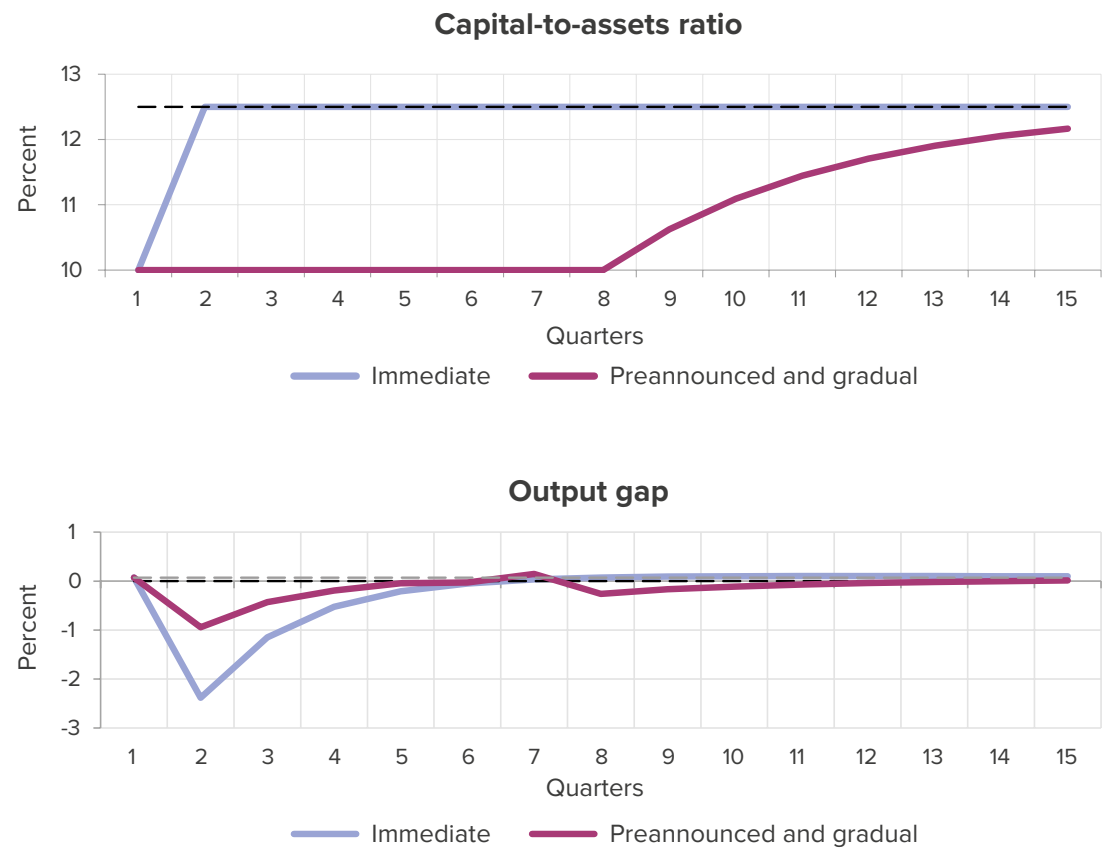